\title{
Dwa zapomniane opowiadania
}

\author{
Pamięci tych co grobów nie mają ${ }^{1}$
}

Siedemnastoletnia, śliczna szarooka dziewczyna konała na gruźlicę. Wielkie rozszerzone grozą śmierci oczy wpatrywały się we mnie i trzymając się kurczowo mojej ręki, szeptała:

- Powiedz, powiedz mi, że nie umrę, że przeżyję i ten listopad. To już mój drugi listopad w Oświęcimiu, a czwarty, jak mnie zamknęli. Boję się listopada. Ale przeżyłam tamte listopady, przeżyję, muszę przeżyć i ten - prawda?

- Prawda. Musisz przeżyć. Są dobre wiadomości, niedługo idziemy do domu, - powiedziałam z mocą.

- Tak, ja też wierzę, że niedługo pójdziemy do domu... Opowiedz mi coś, tak lubię, jak mi opowiadasz, albo jak mi deklamujesz wiersze. Czy wiesz, że ja nie przeżyłam dotąd tego, co ludzie nazywają radością życia? Nie kochałam się w żadnym chłopcu. Nie byłam nigdy nawet na randce. I wiesz, to wstyd aż powiedzieć, - nie byłam nigdy w teatrze dla dorosłych. Kiedy się wojna zaczęła, miałam dwanaście lat. Nic jeszcze wtedy nie rozumiałam...

- Nie męcz się kochanie, nie mów tak dużo, to szkodzi.

- Mnie już nic nie zaszkodzi. Ja wiem.

Wielkie szare oczy złagodniały nagle, a ostre, naznaczone już piętnem zbliżającej się śmierci rysy rozjaśnił jakiś uśmiech nieziemski.

Po chwili zaczęła znowu nerwowo opowiadać.

- Miałam dwanaście skończonych. Trzynaście. Warkocze, mundurek. Chodziłam do szkoły i byłam bardzo rozpieszczona, a tu nagle wojna. Obrona Warszawy. Chodziłam z ojcem kopać okopy. Naloty, bitwy - kapitulacja. W kilka miesięcy potem zabrali ojca. Zginął w Dachau. W dniu, w którym się dowiedziałam o jego śmierci, zapragnęłam wziąć udział w walce o wolność.

\footnotetext{
${ }^{1}$ Pierwodruk w: „Polska Zbrojna” 1945, nr 236 [1 listopada], s. 4.
} 
Obejrzała się trwożnie wokoło i jeszcze ciszej szeptała.

- Byłam kolporterką. Nosiłam gazetki. Miałam już 14 lat, ale wyglądałam wtedy jeszcze bardzo dziecinnie. Ciągle miałam warkocze i granatowy beret. Złapali mnie na ulicy. Miałam przy sobie jeden, ostatni numer. Naturalnie to mnie zgubiło. Zaczęły się badania. Skąd? Kto?... Jakiś pan dał mi w kościele, powtarzałam uparcie ułożoną z góry bajeczkę. Więc bili... Wiesz, tak się zacięłam, że nawet nie krzyczałam. Przestali wreszcie bić. Opatrzyli rany. Na drugi dzień wzięli do biura na białą gorącą kawę z ciastkami i obiecywali, że puszczą, żebym im tylko powiedziała: - Kto dał? Jak wyglądał? Gdzie mieszka, - Nie wiem, jak wyglądał, zapomniałam, zdaje mi się, że taki jakiś wysoki, starszy, podszedł do mnie w kościele i dał. Znów zaczęli bić. A potem odesłali na Pawiak. Na Pawiaku byłam najmłodszą więźniarką. Lubiły mnie wszystkie, opiekowały się jak córką. Teraz dopiero widzę, jak mi tam było z nimi dobrze. Przed samym odjazdem do Oświęcimia jeszcze raz wezwali mnie na Szucha do gestapo i znów: - Kto? Jak się nazywa? Jak wyglądał? A ja jeszcze raz powtórzyłam bajeczkę o panu z kościoła.

Przyszedł Oświęcim, no to już znasz... Komando, praca w polu, apele. Tak się trzymałam, tak się trzymałam, aż przyszło zapalenie płuc, a potem gruźlica. Listopad. Tak się boję listopada. W listopadzie jest święto umarłych. Zawsze chodziłam z mamą na Powązki i nosiłyśmy kwiaty na grób babci. Takie białe chryzantemy...

Chora, zmęczona, przestała na chwilę mówić i ciężko oddychając, przymknęła swoje ogromne gorejące oczy, których nigdy nie zapomnę. Było w nich wszystko: i walka, i bunt, i zrozumienie życia, i strach przed śmiercią, i bezradność okrutnie skrzywdzonego dziecka, i mistyczna pogoda zbliżającej się śmierci. Gładziłam drobną gorącą rękę i serce ściskało mi się z bólu. Wiedziało się, że godziny jej niemal są policzone.

W pewnej chwili powiedziała całkiem głośno.

- A nawet gdybym umarła, to nie wszystkie tu zginiemy, prawda?

- Prawda.

- I musi być sprawiedliwość na świecie i musi być Polska niepodległa prawda?

- Prawda.

Drobna, szarooka dziewczyna użyźniła w kilka dni potem swymi prochami ziemię oświęcimską. Listopadowy wiatr rozwiał jej popiół jak tysiące innych.

Nie można Ci, maleńka, zanieść na grób chryzantemów, nie można Ci zaświecić tradycyjnej lampki. Można tylko Tobie i tysiącom zamordowanych w tej kaźni ludziom złożyć hołd pamięci i czci.

Można wam tylko powiedzieć, że wasza ofiara nie poszła na marne, że na waszych prochach, którymi chcieli użyźnić ziemię, powstała Niepodległa, która o was nie zapomni. 


\section{Dziękuję...2}

Święta Bożego Narodzenia. Barak szpitalny przybrał wygląd świąteczny. Nie wiadomo skąd, znanym tylko więźniarkom sposobem zdobyto i przemycono do obozu dużo małych choinek.

Choinki ubrały pielęgniarki białą, tak zwaną szklaną watą, której w obozie było bardzo dużo w tym okresie i poprzyczepiały wysoko na górnych łóżkach.

Zdrowsze siedzą na łóżkach, robią kanapki z otrzymanych w paczkach zapasów świątecznych, czasem dzielą się opłatkiem przemyconym w paczce, czyjeś głodne, rozszerzone gorączką oczy śledzą każdy ruch ręki tych, co jedzą, każde poruszenie szczęki. Nie wszystkie mają paczkę, a nie wszystkie rozumieją, co to za męka patrzeć na smakołyki, gdy się ma słynny, wilczy, potyfusowy apetyt i dzielą się tylko, niestety, z bliskimi znajomymi.

W końcu baraku ktoś monotonnym, żałosnym głosem od kilkunastu minut śpiewa „Lulajże, Jezuniu”. Poza tym wnętrze baraku wypełnia bezustanny krzyk i jęk konających kobiet. W tych majakach w różnych językach europejskich słyszy się prawie zawsze to samo. Krzyk o ratunek, o pomoc, o trochę wody. Woda jest tu tak samo upragniona, jak na pustyni i tak samo niemal o nią trudno.

Tragiczne Boże Narodzenie 1943. Epidemia tyfusu wzrosła do maksimum. Co dzień przed blokami leży przeszło 300 umarłych. Już się nie nosi ich do trupiarni. Leżą nagie cały dzień przed blokami, w nocy przyjeżdża auto ciężarowe i zabiera do krematorium. Mówi się o tym w bloku bez ustanku.

Na jednym wąskim łóżku leżą po trzy, cztery, tylko na najwyższych piętrach po dwie, bo deski nie wytrzymują zbytniego obciążenia. Oczywiście, nie mamy prześcieradeł. Wstrętne cuchnące sienniki i tak samo brudne koce. Setki wszy chodzi po nas. Myślę, że bardzo dziwny wydałby się taki szpital lekarzowi, którego by ktoś nagle wyprowadził tu z wolności. Barak nie jest wcale ściśle zakaźny. Tyfus leży obok anginy, grypa, malaria, biegunka, świerzb i pęcherzyca, wszystko razem.

Mam tyfus. Głowa ciąży i boli okropnie. Leżę wysoko pod samym sufitem i elektryczna żarówka kłuje mnie w oczy ostrym światłem. Wzywam na pomoc wszystkie siły żywotne, jakie mam jeszcze w sobie, żeby się nie poddać chorobie. Żeby nie stracić przytomności. Wiem, że jeżeli się poddam i zacznę majaczyć tak jak tamte naokoło, to za kilka dni będzie ze mną koniec. Boże, Boże, żeby móc zasnąć, żeby się przez chwilę bodaj uciszyło trochę. Tymczasem leżąca na sąsiednim łóżku chora przeżywa wizję jakiejś wigilii. Nieruchome, rozwarte oczy patrzą w sufit, czarne spieczone usta poruszały się czas jakiś bezgłośnie, ale teraz na cały głos zaczyna wydawać rozkazy: których pobudzone jej wysiłkiem ${ }^{3}$

\footnotetext{
2 Pierwodruk w: „Nowa Epoka” 1946, nr 19/20, s. 10-11.

${ }^{3}$ Zapis oryginalny za pierwodrukiem (autograf ani maszynopis stanowiący podstawę publikacji nie zachował się).
} 
- Mamo, trzeba prędko nakrywać do stołu, zaraz zaczną się schodzić goście na wigilię. Mój Boże, a ja się jeszcze nie ubrałam, oni przecież zaraz przyjdą...

Obok leżąca chora jest rzeczywiście jej matką. Budzi się z jakiejś chwilowej drzemki i zaczyna powstrzymywać wyrywającą się z łóżka córkę:

- Bronka, czyś ty zwariowała, gdzie chcesz iść, co ty pleciesz? Nie rzucaj się, mnie tak głowa boli - mówi całkiem przytomnie i nagle zaczyna krzyczeć: Kury nie dostały jeszcze jeść, dajcie kurom jeść! Nie wolno głodzić zwierząt!!

$\mathrm{Na}$ ten okrzyk jakby w odpowiedzi kilka sąsiadek naraz zaczyna krzyczeć: - Ratunku, ratunku, o Jezu, Jezu najsłodszy, zmiłuj się nad nami! -

Najkoszmarniejsze są te zaśpiewy modlitewne przed śmiercią. Chora wpada w jakiś trans, w którym bez przerwy, czasem przez dwa, trzy dni jednotonnie, przeciągle ni to śpiewając, ni to jęcząc, woła: - Jezu, Jezu, o Matko Boska, zmiłuj się nad nami! Pielęgniarki wiedzą, że jak która już tak zaczyna „śpiewać”, to dłużej niż trzy dni nie pożyje...

Zachować w tych warunkach jaką̧́ formę psychiczną było bardzo trudno, a jednak to był jedyny ratunek: Zachować się do końca jak człowiek. Nie poddać się! Nie pozwolić się opanować bakteriom do tego stopnia, żeby stracić kontrolę nad swoimi myślami. Tymczasem gorączka zwiększa się z godziny na godzinę.

Nagle widzę siebie idącą przez cudowny oszroniony gaj. Drzewa mają fantastyczne, bajkowe kształty. O, to wcale nie są zwyczajne drzewa! Szron też nie jest zwyczajny. Nadnaturalnie puszysty, iskrzący się miliardami brylantowych światełek. Widzę kręte, śliczne, białe dróżki. Przechodząc obok niższego, oszronionego drzewa, zawadzam głową o gałązkę i czuję na twarzy błogosławione, chłodne jej dotknięcie. Przychodzi mi na myśl, że można po prostu wysunąć język i zlizywać szron. Zaczynam żarłocznie ogryzać oszronione gałęzie i ogarnia mnie uczucie niesłychanej rozkoszy zaspokojonego pragnienia... Słyszę, że gdzieś bardzo daleko dzwonią delikatnie srebrne dzwoneczki, które się przybliżają coraz bliżej, bliżej, i normalnym głosem ktoś mówi obok: Straciła przytomność niedawno. Jeszcze godzinę temu rozmawiała ze mną całkiem przytomnie.

- Z największym wysiłkiem otwieram oczy i widzę pielęgniarkę Marysię i jedną z moich zdrowych koleżanek, która się przekradła na „revier”, żeby mi przynieść $\mathrm{z}$ wielkim trudem ugotowany kompot $\mathrm{z}$ jabłek, które dostałam w świątecznej paczce. Widzę, że mam przy ustach kubek i czuję jego realny chłód. A może nie warto wracać tu?... Tak cudownie było tam w tym oszronionym lesie. Lecz jakaś moc ukryta we mnie szepce mi: nie wolno poddawać się majakom!

Zdobywam się więc na najwyższy wysiłek woli i mówię wolniutko i wyraźnie:

- Dziękuję, bardzo dziękuję. Wcale nie straciłam przytomności, tylko byłam w...

- Nie, nie, naturalnie, że nie straciłaś przytomności, - powiadają prędko obie, - masz zupełnie normalny przebieg. 
- Jutro postaram się dla ciebie o zastrzyk nasercowy - mówi pielęgniarka Marta. A Janina pochyla się nade mną i szepce tajemniczo:

- Tylko się nie poddawaj chorobie. Głowa do góry! Są świetne wiadomości. Niedługo idziemy do domu.

Jakiś ruch w okolicy pokoiku blokowej spłoszył je nagle. Zesunęły się prędko z łóżka i znikły. Tymczasem mnie ogarnia poczucie niewysłowionej samotności. Wydaje mi się, że mnie ktoś nagą z łóźkiem wyniósł na plac, gdzie sprzedają choinki. Jest tak okropnie zimno i źle, zaczynam szczękać zębami. Zewsząd otacza mnie krzyk i gwar jarmarczny i nagle wszystkie choinki zaczynają maszerować na mnie. Kulę się, bronię, osłaniam rękami, a one idą, idą coraz bliżej...

I znów słyszę głos: - Uważaj, nie zrzucaj koca z siebie. Wieje z dachu, przeziębisz się.

Moja sąsiadka leżąca obok w łóżku już po kryzysie, otula mnie troskliwie kocem, a ja znów zdobywam się na najwyższy wysiłek woli i mówię przytomnie: - Dziękuję! 